\title{
OBJECT OF TAXATION UNDER DIGITALIZATION
}

\author{
Olga I. Lyutova \\ National Research University «Higher School of Economics» \\ 11 Myasnitskaya srt., 101000, Moscow, Russian Federation
}

\begin{abstract}
The article investigates the problem of content change of the concept object of taxation in the Russian tax law on the path to digital economy. The purpose of the article is to analyze the provisions of the Russian tax legislation, international norms, as well as academic literature devoted to identification of certain new goods and phenomena as possible objects of taxation, thus updating the concept of the object of taxation itself. The development of information technologies generates the following unavoidable problems related to the object of taxation concept content, which allows reviving the discussion about the content of this tax and legal category: the impossibility to assess implementation operations as potential tax objects with the help of the classical triad «product, work, service»; recognition in certain situations (for example, in case of electronic money payment) as the object of taxation is not one, but a set of legal facts (cause of action); the need to establish the object of taxation through the so-called «tax relationship» between the object and the subject of taxation. In connection with the first problem, the author proposes to unambiguously define in the Tax Code the legal nature of transactions with digital products for tax purposes, treating them as a new type of service. The conclusion is based on the experience of international regulation and suggests supplementing the provisions of the Tax Code in terms of legal regulation of the concept taxation object as well as VAT taxation. The re-search of the second problem leads to the conclusion that it is necessary to clarify the rules of the Tax Code when the counterparties carry out taxable transactions, whose settlements are made with electronic money. In this situation, the object of taxation is not single, but suggests several legal facts-actions of the potential tax-payer. On the third problem the author raises the issues of identification of the taxpayer in case of certifying the taxable transaction by the digital signature analogue. Taking into account international experience, as well as national civil law regulations, it is considered necessary to include provisions on digital certificates and digital signatures in tax legislation.
\end{abstract}

Key words: electronic commerce, digital economy, tax object, legal fact, legal composition, digital goods, electronic money, «tax forming communication», analogue of digital signature

Conflicts of interest. The authors declared no conflicts of interest.

Financial support: the work was supported by RFBR grant № 18-29-16107 mc on the issue: «Research and justification of the choice of tax model in the era of digital transformation».

Article received March 23, 2020

Article accepted June 30, 2020

(C) Lyutova O.I., 2020.

This work is licensed under a Creative Commons Attribution 4.0 International License https://creativecommons.org/licenses/by/4.0 


\section{For citation:}

Lyutova, O.I. (2020) Object of taxation under digitalization. RUDN Journal of Law. 24 (3), pp. 695-716. DOI: 10.22363/2313-2337-2020-24-3-695-716.

\section{Introduction}

The global character of the digitalization process allows researchers to seriously characterize the ongoing transformation of social and economic relations as a new (fourth) technological revolution. It is being shaped by the rapid development of information and communication technologies, which in turn increases the role of legal regulation of relations emerging in the digital society. This process is associated with an objective need for scientific reflection on a number of phenomena resulting from the digitalization and informatization of society, which has been repeatedly stated in legal literature (Habrieva, 2018:19; Blazheev, Egorova, 2020:5-13). There is also a growing need to address a number of practical issues related to legal support for the digitalization of the economy and other areas of public life.

In the legal doctrine it is becoming more and more relevant to carry out sectoral legal and interdisciplinary research on the current social and technological changes in terms of revising the classical notions used both in science and in the texts of normative acts. In tax law, this approach is already being implemented, for example, categories of tax legal personality (Lyutova, 2019:40-42), tax sovereignty (Andreev, 2018:13-16; Khavanova, 2017:34-38) and others. This is evidenced not only by numerous publications of articles, monographs and educational literature, but also by grants studying the processes of digitalization and related international integration directly through the prism of a sectoral approach.

A number of works on tax law pay considerable attention, as noted E.G. Belikov, to the issues of legal regulation of the objects of taxation definition in respect of taxes arising from activities in the markets for digital services (for example, in the field of electronic commerce, using the technology of distributed registers) (Belikov, 2019:23-26) Such problems require further research, which is conditioned by the impossibility to apply the traditional approach to the definition of the tax object in the new economic reality. The implementation of digitalization concept necessitates to clarify the object of taxation concept and to establish appropriate tax consequences in respect of new business models, for example, various types of electronic commerce in the form of sale of goods and trade in access to intangible assets and/or objects of intellectual property (Pokrovskaya, 2016:171). Some scholars argue that the object of taxation for such transactions is specific. For example, the income as a result of new digital processes, recognition of which as taxation object requires special tax structures allowing objectively assess, as well as fairly and efficiently withdraw part of the income without slowing down the pace of economic development (Koroleva, 2019:92).

We will be interested to look at the problem of revising the theoretical definition of the object of taxation concept in the new conditions and discussions on qualifi- 
cation of tax consequences of the sale of digital goods in electronic commerce. At the same time, doctrinal rethinking of the object of taxation concept has quite pragmatic goals: according to N.T. Mambetaliev's fair comment, "dynamically developing branch of e-commerce expands the list of objects subject to tax collection..." (Bukach, 2017:10-16). Thus, the definition of the taxation object adequate to the current realities will allow to objectively assess the tax consequences of entrepreneurial activity for business in conditions of digitalization, as well as to fairly and efficiently withdraw part of the income to the state treasury; this can be done without slowing down economic growth, while ensuring and protecting both private and public interests.

\section{Subject of taxation definition in contemporary science}

It should be noted that the issues of definition of the object of taxation concept occupy a significant place in the scientific works of domestic legal scholars specializing in tax law: K.N. Grigorov, O.O. Zhuravleva, M.F. Ivlieva, I.I. Kucherov, S.G. Pepeliaev, D.A. Smirnov, V.A. Churkin and others. The problems of determining the object of taxation in the conditions of economy digitalization, as well as the need to expand the list of the taxation objects with certain types of income are investigated; this issue is investigated, for example, with regard to the tax on professional income in the works of A.A. Kopina, S.M. Mironova, E.Y. Stetsenko and others.

The review of some foreign scientific works on tax law and taxation showed that there are scientific publications in the field of general theoretical concept of the object of taxation and its relation to related concepts (Kucheryavenko, 2003:11-13).

At the same time, it may be noted that there is no consistent approach to the definition of the object of taxation concept and the need to establish criteria for attributing certain events to the taxation objects, which determines the relevance of the issue taking into account modern tendencies in the development of science and tax law practice.

It is traditional for Russian tax law to characterize the object of taxation by listing the phenomena related to it, an open list of which is contained in Article 38 of the Tax Code: sale of goods (works, services), property, profit, income, expense or other circumstance. As it is known, the legislative wording of the object of taxation concept is applied from the moment when the first part of the Tax Code of the Russian Federation came into force. At the same time, attempts to develop any qualifying features of the object of taxation, which would allow to unambiguously identify certain objects and phenomena as objects of taxation, as well as classifying them, have not been successful to date. However, researchers and practitioners specializing in tax law have formed two different approaches to the definition of the object of taxation concept, which can be conventionally denoted as economic and legal.

Representatives of economic sciences believe that the only right thing to do is to further develop the legislatively established idea to formulate the object of taxation concept exclusively by listing various objects. In this case, their task is to assess one or another object as to whether it is possible and/or necessary to establish liability to pay tax on it. This approach was studied in detail in the dissertation of A.V. Churkin, 
who was one of the first to raise the issue of object of taxation concept definition and its delimitation from related scientific categories. (Churkin, 2002:11).

Lawyers, in their turn, consider the object of taxation as a legal fact, entailing obligation to pay tax (Pepelyaev, 2001:89; Ivlieva, 1997:39). At the same time, only those legal facts that are conscious volitional actions of taxpayers or their results, namely, actions related to the sale of goods, works, services or income, are recognized as objects of taxation. As it is known, depending on the identification of an object as goods, works or services, the tax law establishes various legal and related financial consequences in respect of transaction (Articles 38-39 of the Tax Code), for example, in calculation and payment of VAT.

In our opinion, the initial refusal to develop criteria for determining the object of taxation, implemented in economic science, implies a high degree of subjective discretion of the state when classifying an object as one of those suggesting tax obligations. All this leads to the idea that, basically, taxes can be levied on almost anything. In any case, such judgments are found in the works of other authors as well (Karagusova, 1994:17). It would be impossible, therefore, to contrast the economic and legal approaches, as they are complementary and specific to each other. It should be remembered that economic science and legal theory have similar phenomena: the former studies how to produce, distribute and consume goods more efficiently, the latter studies how to do it rightly and legitimately (Napso, Napso, 2019:161). This allows for a balance in the expression of public and private interests through recognition of the coercive power of law, based on a reality analysis. Thus, at present, the phenomena listed in the Tax Code of the Russian Federation are recognized as the object of taxation, which have the statutory characteristics (monetary, quantitative, physical) and are legal facts and actions.

Under the circumstances the author asserts that it is possible to use the principles of economic analysis to develop models of legal regulation and specific rules. Studying the mutual influence of the economy on tax law, A. Raskolnikov, generally expresses similar thoughts, regardless of digitalization (Shaviro, 2014:455).

\section{Challenges in defining the tax object in the digital era}

In the context of implementation of the National Program "Digital Economy" in modern Russia, the three principal problems arising in the definition of the object of taxation concept are the following: objective impossibility to assess realized transactions as potential objects of taxation with the help of the classical triad of "product, work, service"; recognition that the object of taxation is not a single legal fact, but a set of legal facts; revision of the issue of establishing the object of taxation through the so-called "tax-forming relationship" of the object and subject of tax.

The first problem, connected with the lack of universality in the approach to identification of the phenomena as taxation objects through the triad "product, work, service" can be demonstrated in attempt to apply it to the digital goods typical for In- 
ternet trade. There is currently no definition of such goods, as well as of the digital market where they are traded, both at the legislative level and in judicial and other law enforcement practice, as noted by experts (Kadar, 2015:342). In science, so far, there is only a discourse on the issue of assigning various types of cryptocurrencies to them (Savelyev, 2017:136-153). At the same time, a significant number of various products which hypothetically can be described as digital, are being traded. This means that transactions with such goods require adequate legal assessment, including in terms of their tax and legal consequences.

In reality, digital goods can, for example, be downloaded from the manufacturer's website, without the need to transfer its material carrier. This means that it can be realized by sending by e-mail or by uploading to the Internet, organizing appropriate access. Usually, digital products are texts, sounds and video files. It is often difficult to determine which type of product is a digital product, whether it acts as an asset, work or service. For example, in case a digital product is in the form of a temporary link to a training text file or video (audio) record on the site, the nature of such a legal fact is controversial in terms of the classic triad of "products, work, service". From the point of view of tax law there is a question: Has a buyer purchased a training service, a license to use the site, a communication service or goods in the form of the training information itself? In case of identifying it as the goods transfer, can we talk about the transfer of ownership? No. Due to the limited time of use. From these positions, it turns out that in case of information transfer by reference to the consumer for his/her permanent use (both options, permanent and/or temporary access, are possible depending on the cost) the possibility to identify it as a product or service that does not have the appropriate result is highly disputable (for example, in case of purchasing a video lesson).

A good example is the European Union regulation of taxation issues concerning digital goods. The content and meaning of the European Union Directive allows to conclude that digital and electronic products should be recognized as "services provided electronically" (European Union Council Regulation № 282/2011 "Establishing Measures for the Implementation of Directive 2006/112 / EC on the General System of Value Added Tax (as amended)"). It also provides a list of such services including server software, hosting of clients' websites, remote maintenance of programmes and equipment, supply of software and its updating, supply of images, texts and information and access provision to databases, supply of music, films and games, including gambling, and political, cultural, artistic, sports, scientific and entertainment broadcasts and broadcasts, supplying distance learning. Thus, for all countries of the European Union, the sale of digital products is considered a new type of service. Since the Russian Federation does not participate in the documents of the European Union, its territory requires its own legal regulation concerning identification of digital products as works or services both at the level of national law and in the acts of the international communities of which it is a member. D.A. Mitin supposes that a good solution may be reached through establishing definitions of digital products and 
digital delivery as categories in the Russian tax legislation or in a special legislative act related to legal regulation of digital rights; it is also necessary to define the list of digital products. In his opinion, this will facilitate determination of the taxable entity in cases where digital goods are traded (Mitin, 2018:36-39). It should be assumed that in addition to the actual definition of the legal nature of digital goods, it is also essential to supplement the definition of the object of taxation concept in paragraph 1 of Article 38 of the Tax Code in terms of listing the services provided, and defining their types in analogy with the list presented in the European Union Directive 2006/112/EC. We also consider it logical to supplement Article 146 of the Tax Code with special rules related to calculation and payment of VAT on digital goods, understood in the meaning of electronic services. This would allow the law enforcer to unambiguously consider all digital deliveries as a new type of service, applying the relevant rules and tax rate.

From the point of view of determining the legal nature of new digital phenomena in order to attribute them to the taxation objects, it is interesting to assess the phenomenon of cryptocurrencies («virtual currencies») using the triad "product, work, service". It is known that in the Russian Federation most transactions with cryptocurrencies are currently conducted outside of legal regulation, and cryptocurrencies themselves are not guaranteed or provided for by the Central Bank of Russia (Information of the Bank of Russia dated 04.09.2017 "On the use of private "virtual currencies" (cryptocurrencies)"). It is quite rightly noted in the analytical materials that, based on the requirements of modern legislation, cryptocurrencies (bitcoins, in particular) do not meet the requirements usually imposed on money; they cannot perform all their functions (Yermak, 2013).

Variants of qualification of bitcoin and other kinds of cryptocurrencies presented in Russian and foreign scientific literature are diverse. In fact, they are assessed as an asset that can be described as a component of an investment portfolio, foreign currency, quasi-currency, vouchers (Lambooij, 2014:140) and the like. Cryptocurrency is most often regarded as a type of property, as a commodity or a so-called «economic asset» (Matsuura, 2016:45-47).

It may be noted that legal regulation of the consequences of transactions made with cryptocurrencies in foreign countries is prior to the issue of determining their legal nature. For example, the most comprehensive tax and legal regulation of the use of block technologies and virtual money, both at the federal level and in the regulatory acts of states (subjects of the federation), has been created in the USA to date. Cryptocurrencies in this state are qualified as property, investment instrument or foreign currency (Wiseman, 2016: 416-440). Therefore, most often cryptocurrencies are identified with the help of known legal terms and constructions based on the so-called "barter" approach, which is implemented through the transfer of civil law terminology to tax relations.

Barter approach has also raised huge criticism, arguing that the rules created for transactions with traditional property do not take into account the fundamental 
feature of virtual currencies (the use as a means of exchange and mechanical application of old principles) and leads to poor results. This approach is assessed as imperfect, not feasible and/or difficult to implement from the perspective of promoting rules (Hampton, 2016:331, 334).

A similar approach to establishing taxation rules prior to determining their legal nature is applied in Russia. Thus, the Russian Finance Ministry believes that operations with cryptocurrencies should be taxed on personal income (Letter of the Ministry of Finance of Russia dated October 13, 2017 № 03-04-05 / 66994), recalling that in accordance with the provisions of Article 228 of the Tax Code of the Russian Federation, individuals should calculate and pay the tax themselves, receiving remuneration from individuals on the basis of civil law contracts. In other words, if one natural person sells bitcoins to another natural person, he/she should independently determine the tax base, report on the income received, calculate and pay the tax. In this case, the Ministry refers to the provisions of Article 41 of the Tax Code on the definition of income.

It should also be noted that a few years ago the Bank of Russia warned citizens and legal entities against the use of "virtual currencies" for the exchange of goods (works, services) or money in rubles and foreign currency (Information of the Bank of Russia dated January 27, 2014 "On the use of "virtual currencies"', Bitcoin, in particular, when making transactions).

The second problem associated with the definition of the object of taxation concept in the digital age is the need to consider not a single legal fact, but their set as such object. An example is payment for goods traded with electronic money as the equivalent of real money (fiat, as it was called by John Maynard Case (Cesarano, 2008:124), the nominal value of which is set and guaranteed by the state, regardless of the value of the material it is made of or stored in the bank's vault), but traded only within a specific electronic payment system (Yandex. Money, QIWI, E-port and others) (Grishina, 2019:21-27). The mechanism of settlement with electronic money is based on the right of the owner of electronic money to redeem it from the operator (exchange for cash or non-cash funds). Electronic money is recorded in a special virtual account ("e-wallet"), while the money account is reflected in the bank account of the electronic money operator, due to which all electronic money accounted by the electronic money operator will be redeemed. Another important detail is that prior to the transfer of e-money, cash or non-cash payments are supposed to be made in advance; only after that it is possible to make a payment and the e-money operator transfers the e-money to the recipient. The transfer can be made by the payer's order or at the recipient's request. Electronic funds are debited from the payer's virtual account ("electronic wallet") and credited to the payee's virtual account (Tsindeliani, 2019:219).

It should be noted that, according to the official position of the Russian Ministry of Finance, the income received from payment for purchased goods with electronic money is subject to taxation (Letter of the Russian Ministry of Finance No. 03-11-11 / 1415 dated 01.20.2014), and the fact of payment is confirmed by a statement on the re- 
spective account with the payment system operator or a message from the payment system operator (Letter of the Russian Ministry of Finance No. 03-11-11 / 163 dated 05.06.2013). Therefore, the taxation object in this case may arise as a result of not one but two legal facts, one of which is a security condition in relation to the second.

At the same time, there are no changes in the tax legislation of the Russian Federation related to the need to fix the consequences of not one but two legal facts for establishing obligation to pay tax in respect of a particular subject of tax. We believe that it would be logical in this regard to adjust paragraph 1 of Article 38 of the Tax Code on defining the object of taxation and indicate that it may be a set of facts. Such set includes not only a circumstance, but also a set of circumstances, one of which has a value characteristic and the other is of organizational and supporting nature.

The third digitization challenge to the tax law in terms of formulating the object of taxation concept is the issue of establishing the necessity of the tax-forming connection between the object of taxation as a phenomenon of the material world and a potential taxpayer when determining the tax. E.V. Porokhov stated about the existence of such connection, defining it as a stable legal connection of the subject of tax with the subject of taxation (Porokhov, 2001:99). I.I. Kucherov emphasized the importance of this connection for the real establishment of the fact of presence or absence of the object of taxation in the activities of a potential taxpayer: "This connection is decisive, because, in our opinion, it forms the object of tax - the most important element of its legal construction" (Kucherov, 2009:2-5). In practical terms it means that in order to attribute a legal fact to the objects of taxation it is necessary to establish a legal connection of the object of the material world (object of tax) with an individual, having at the same time a mechanism of unambiguous identification of the latter. In the conditions of digitization, there are identification difficulties of the parties to a transaction, as well as their location and status when performing electronic transactions, which is significant from the tax point of view.

One of manifestations of such problem is the question of legality of transaction certification when using analogues of handwritten signature.

As a temporary solution to the problem, it was suggested that the Organization for Economic Cooperation and Development should use digital certificates and digital signatures to identify parties to taxable transactions, which would help to identify a particular entity as a taxpayer related to a certain benefit for which the State could impose an obligation to calculate and pay tax.

As it is known the civil legislation of the Russian Federation regulates the use of analogues of handwritten signature in a transaction (paragraph 2 of Art. 160 of the Civil Code). The researchers note that the "projection" of these provisions on tax and other relations that are not civil law, is possible only if there is a corresponding indication of this possibility in the law. It seems that the difficulty of applying digital certificates and digital signatures by the parties to the transaction, the consequences of which are taxable, is due to the absence of such special provisions in the tax legislation. 


\section{Conclusion}

Therefore, the result of the course taken by the state to develop the digital economy is a significant transformation of both tax law theory and its legal regulation. In order to introduce new technologies in tax relations it seems necessary to carry out research aimed at development of separate, though rather narrow, but indisputably important issues connected with application of digital technologies in legal sphere (Khabrieva, 2018:6). For this reason, issues related to the definition of the subject of taxation require further study and development.

The review of academic literature on the issue of definition of one of the most important terms of the tax law - object of taxation - conducted within the framework of the present article allows to highlight existence of two approaches; both of them seem far from ideal taking into account modern digital challenges to Russian economy. Besides, the tax and legal terminology needs to be unambiguously updated due to the normative definition of digital goods.

It seems that the main drawback of the current definition of the object of taxation is the obsolescence of approaches to its formulation. In our opinion, there is a need for the doctrinal concept of transformation of tax relations with regard to the digital age; then further improvement of tax legislation will become real. At the same time, such concept should focus on the development of new terminology, as well as the methodology adequate to the digital realities, which implies the use of a comprehensive approach for the purposes of tax law. Such approach should combine legal, economic and sociological knowledge along with information technologies.

The practical value of such approach is to create a universal triune formula "legal regulation, public administration, technology", which serves as the main conceptual idea for further digitalization of both the Russian economy and the activities of government agencies. Indeed, successful introduction of some or other new technologies into the processes of interaction between private and public entities can be successfully realized only in case of preliminary substantiation of managerial decisions based on such technologies, as well as corresponding modifications in normative legal and individual regulation.

We believe that the idea of ensuring the unity of technology, law and public administration is of conceptual value not only in relation to certain areas, such as taxation. In our opinion, it is characterized by its universal character; in this connection it should be used as a methodological basis for digital transformation of state and municipal bodies' activities.

\section{References / Библиографический список}

Andreev, N.Yu. (2018) Tax Sovereignty and Digital Economy: Digital Permanent Representation. Financial Law. 12, 13-16. (in Russian).

Андреев Н.Ю. Налоговый суверенитет и цифровая экономика: цифровое постоянное представительство // Финансовое право. 2018. № 12. С. 13-16. 
Belikov, E.G. (2019) Tendencies of the social and innovation-driven development of tax laws in the digital economy conditions. Taxes. 4, 23-26. (in Russian).

Беликов Е.Г. Тенденции социально и инновационно направленного развития налогового законодательства в условиях цифровой экономики // Налоги. 2019. № 4. С. 23-26.

Blazheev, V.V., Egorova, M.A. (eds.) (2020) Tsifrovoye pravo: uchebnik [Digital law: textbook]. Moscow: Prospect Publ. (in Russian).

Цифровое право: учебник / под общ. ред. В.В. Блажеева, М.А. Егоровой. Москва: Проспект, 2020. 640 c.

Bukach, E. (2017) The main directions of international taxation in the EAEU [Interview with N.T. Mambetaliev]. Tax Bulletin - Consultations. Explanations. Opinions. 9, 10-16 (in Russian).

Букач $E$. Основные направления международного налогообложения в ЕАЭС [Интервью с Н.Т. Мамбеталиевым] // Налоговый вестник - Консультации. Разъяснения. Мнения. 2017. № 9. С. 10-16.

Cesarano, F. (2008) Money and monetary systems. Cambridge University Press.

Churkin, A.V. (2002) The concept of the object of taxation and the problems of its definition in the legislation: Author. dis. ... cand. legal sciences. Moscow. (in Russian).

Чуркин А.В. Понятие объекта налогообложения и проблемы его определения в законодательстве: Автореф. дис. ... канд. юрид. наук. М. 2002. 26 с.

Grishina, O.P. (2019) Oplata pokupatelem uslug svyazi cherez elektronnyi koshelek [Payment by the buyer of communication services through an electronic wallet]. Uslugi svyazi: bukhgalterskii uchet $i$ nalogooblozhenie [Communication services: accounting and taxation]. 1, 21-27. (in Russian).

Гришина О.П. Оплата покупателем услуг связи через электронный кошелек // Услуги связи: бухгалтерский учет и налогообложение. 2019. № 1. С. 21-27.

Hampton, S. (2016) Undermining Bitcoin. Washington Journal of Law. Technology \& Arts. Vol. 11, Iss. 4. 331-334.

Ivlieva, M.F. (1997) K ponyatiyu naloga i ob"ekta nalogooblozheniya [To the concept of tax and the object of taxation]. Vestnik MGU. Seriya 11. Pravo [Bulletin of Moscow State University. Issue 11: Law]. 3, 37-39. (in Russian).

Ивлиева М.Ф. К понятию налога и объекта налогообложения // Вестник МГУ. Серия 11. Право. 1997. № 3. С. 37-39.

Kadar, M. (2015) European Union competition law in the digital era. Zeitschrift fur Wettbewerbsrecht. No. 4. 342-368.

Karagusova, G. (1994) Nalogi: sushchnost' i praktika ispol'zovaniya [Taxes: the nature and practice of use ]. Almaty: Ekonomika Publ. (in Russian).

Карагусова Г. Налоги: сущность и практика использования. Алматы: Экономика. 1994. $47 \mathrm{c.}$

Koroleva, L.P. (2019) Taxation of digital services: theory, international practice and domestic prerequisites. Economic and social changes: facts, trends, forecast. 12 (3), 91-106. (in Russian).

Королева Л.П. Налогообложение цифровых услуг: вопросы теории, зарубежной практики и отечественных предпосылок // Экономические и социальные перемены: факты, тенденции, прогноз. 2019. Т. 12. № 3. С. 91-106.

Khabrieva, T.Ya. (2018) Law facing challenges of digital reality. Journal of Russian Law. 9, 5-16. (in Russian).

Хабриева Т.Я. Право перед вызовами цифровой реальности // Журнал российского права. 2018. № 9. С. 5-16.

Khavanova, I.A. (2017) Tax jurisdiction: a new reading. Financial law. 5, 34-38. (in Russian).

Хаванова И.А. Налоговая юрисдикция: новое прочтение // Финансовое право. 2017. № 5. C. 34-38. 
Kucherov, I.I. (2009) The value of the subject and source of taxation for the legal construction of tax. Financial Law. 5, 2-5. (in Russian).

Кучеров И.И. Значение предмета и источника налогообложения для юридической конструкции налога // Финансовое право. 2009. № 5. С. 2-5.

Kucheryavenko, N.P. (2003) The object of the tax relationship and the object of taxation: the content and correlation of concepts. Financial Law. 3, 11-13. (in Russian).

Кучерявенко Н.П. Объект налогового правоотношения и объект налогообложения: содержание и соотношение понятий // Финансовое право. 2003. № 3. С. 11-13.

Lambooij, M. (2014) Retailers Directly Accepting Bitcoins: Tricky Tax Issues? Finance and Capital Markets (formerly Derivatives \& Financial Instruments), Volume 16, No 3. 138-144.

Lyutova, O.I. (2019) The legal personality of cryptocurrency market participants: new approaches. Taxes-Journal. 2, 40-42. (in Russian).

Лютова О.И. Налоговая правосубъектность участников рынка криптовалют: новые подходы // Налоги-журнал. 2019. № 2. С. 40-42.

Matsuura, J.H. (2016) Digital Currency: An International Legal and Regulatory Compliance Guide. Bentham Science Publishers. DOI: 10.2174/97816810822331160101.

Mitin, D.A. (2018) E-Commerce Taxation: Russian and European Experience. Taxes. 6, 36-39. (in Russian).

Митин Д.А. Налогообложение электронной коммерции: российский и европейский опыт // Налоги. 2018. № 6. С. 36-39.

Pepelyaev, S.G. (2001) Osnovy nalogovogo prava [Fundamentals of tax law]. Moscow, Yurist Publ. (in Russian).

Пепеляев С.Г. Основы налогового права. М.: Юрист. 2001. 343 с.

Pokrovskaya, N.N. (2016) Problemy nalogooblozheniya innovatsionnykh biznes-modelei $v$ tsifrovoi ekonomike [Problems of taxation of innovative business models in the digital economy]. Russian Economy in the Context of Resource Constraints: a collection of scientific papers based on the results of a scientific and practical conference of young scientists at St. Petersburg State University of Economics. St. Petersburg: Publishing House of St. Petersburg State University. (in Russian).

Покровская Н.Н. Проблемы налогообложения инновационных бизнес-моделей в цифровой экономике // Экономика России в условиях ресурсных ограничений: сборник научных трудов по итогам научно-практической конференции молодых ученых Санкт-Петербургского государственного экономического университета. СПб: Издательство Санкт-Петербургского государственного университета, 2016. 559 с.

Porokhov, E.V. (2001) Teoriya nalogovykh obyazatel'stv: Uchebnoe posobie [Theory of Tax Obligations: A Training Manual]. Almaty, Jetı Jarg1 Publ. (in Russian).

Порохов E.B. Теория налоговых обязательств: Учебное пособие. Алматы: Жеты Жаргы. 2001. 168 с.

Savelyev, A.I. (2017) Cryptocurrencies in the system of objects of civil rights. Law. 8, $136-153$. (in Russian).

Савельев А.И. Криптовалюты в системе объектов гражданских прав // Закон. 2017. № 8. С. 136-153.

Shaviro, D. (2014) The Economics of Tax Law. New York University Public Law and Legal Theory Working Papers.

Tsindeliani, I.I. (ed.) (2019) Finansovoye pravo v usloviyakh razvitiya tsifrovoy ekonomiki: monografiya [Financial law in the development of the digital economy: monograph]. Moscow, Prospect Publ. (in Russian). 
Финансовое право в условиях развития цифровой экономики: монография / К.Т. Анисина, Б.Г. Бадмаев, И.В. Бит-Шабо и др.; под ред. И.А. Цинделиани. М.: Проспект, 2019. 320 с.

Napso, M.D., Napso, M.B. (2019) X Perm Congress of Jurists «Modern Economics in the Legal Dimension». Lex Russica. 12, 152-165. (in Russian).

Hanco М.Д., Напсо М.Б. Х Пермский конгресс ученых-юристов «Современная экономика в юридическом измерении» (статья редакционная) // Lex russica. 2019. № 12. C. $152-165$.

Yermak, D. (2013) Is a Bitcoin a Real Currency? An Economic appraisal. NBER Working papers series. Cambridge, 2013, available at: http://www.nber.org/papers/w19747.pdf.

Wiseman, S.A. (2016) Property or Currency? The Tax Dilemma behind Bitcoin. Utah Law Review. (2). 417-440.

\title{
About the author:
}

Olga I. Lyutova - Candidate of Legal Sciences, researcher of the Institute of State and Municipal Management of the National Research University Higher School of Economics

ORCID ID: 0000-0002-6603-8859

e-mail: olyutova@hse.ru

\section{ОБЪЕКТ НАЛОГООБЛОЖЕНИЯ В УСЛОВИЯХ ЦИФРОВИЗАЦИИ}

\author{
О.И. Лютова
}

Национальный исследовательский университет «Высшая школа экономики» 101000, г. Москва, Российская Федерация, ул. Мясниикая, д. 11

Статья посвящена проблеме изменения содержания понятия объекта налогообложения в российской науке налогового права в условиях взятого курса на цифровую экономику. Цель статьи - провести анализ положений российского налогового законодательства, международных норм, а также академической литературы по вопросу идентификации тех или иных новых предметов и явлений в качестве возможных объектов налогообложения, тем самым актуализировав понятие самого объекта налогообложения. Развитие информационных технологий порождает следующие неизбежные проблемы, связанные с содержанием понятия объекта налогообложения, что позволяет возродить дискуссию о содержании этого налогово-правового понятия: невозможность оценки реализационных операций в качестве потенциальных объектов налогообложения с помощью классической триады «товар, работа, услуга»; признание в отдельных ситуациях (например, при расчете электронными деньгами) в качестве объекта налогообложения ни одного, а совокупности юридических фактов (юридического состава); необходимость установления объекта налогообложения через так называемую «налогообразующую связь» предмета и субъекта налога. В связи с возникновением первой проблемы автор предлагает однозначно определить в НК РФ правовую природу реализационных операций цифровых продуктов для целей налогообложения, отнеся их к новому виду услуг. Вывод основывается на опыте международного регулирования и предполага- 
ет дополнения положений НК РФ в части правового регулирования понятия объекта налогообложения, а также налогообложения НДС. Исследование второй проблемы позволяет сделать вывод о необходимости уточнения нормы НК РФ при осуществлении контрагентами налогооблагаемых операций, расчеты по которым производятся с использованием электронных денег. В этом случае объектом налогообложения является не один, а несколько юридических фактов-действий потенциального налогоплательщика. По третьей проблеме автор предлагает обсудить вопросы идентификации налогоплательщика в случае удостоверения им налогооблагаемой сделки аналогом цифровой подписи. С учетом международного опыта, а также национального гражданско-правового регулирования сделан вывод о необходимости включения в налоговое законодательство положений о цифровых свидетельствах и цифровых подписях.

Ключевые слова: цифровизация, цифровая экономика, объект налогообложения, юридический факт, юридический состав, цифровой товар, электронная торговля, электронные деньги, «налогообразующая связь», аналог цифровой подписи

Конфликт интересов. Автор заявляет об отсутствии конфликта интересов.

Информация о финансировании. Работа выполнена при поддержке гранта РФФИ № 18-29-16107 мк на тему: «Исследование и обоснование выбора модели налогообложения в эпоху цифровой трансформации».

Дата поступления в редакиию: 23 марта 2020 г.

Дата принятия к печати: 30 июня 2020 г.

\section{Для цитирования:}

Лютова О.И. Объект налогообложения в условиях цифровизации // Вестник Российского университета дружбы народов. Серия: Юридические науки. 2020. Т. 24. № 3. С. 695716. DOI: 10.22363/2313-2337-2020-24-3-695-716.

\section{Введение}

Глобальность процесса цифровизации позволяет исследователям всерьез характеризовать происходящую трансформацию социальных и экономических отношений как новую (четвертую) технологическую революцию. Она разворачивается под влиянием ускоренных темпов развития информационных и коммуникационных технологий, что, в свою очередь, повышает роль правового регулирования отношений, складывающихся в цифровом обществе. Этот процесс сопровождается объективной необходимостью научного осмысления ряда феноменов, появившихся вследствие цифровизации и информатизации общества, на что неоднократно указывалось в юридической литературе (Khabrieva, 2018). Также возрастает необходимость решения ряда практических задач, связанных с правовым обеспечением цифровизации экономики и других сфер общественной жизни.

В правовой доктрине становится все более актуальным осуществление отраслевых правовых и междисциплинарных исследований происходящих социальных и технологических изменений, и, прежде всего, с точки зрения переосмысления классических понятий, используемых как в науке, так и в текстах нормативных актов. Для налогового права такой подход уже реализуется в отношении, например, категорий налоговой правосубъектности (Lyutova, 2019:40-42), налогового суверенитета (Andreev, 2018:13-16) и других. Об этом 
свидетельствуют не только многочисленные публикации статей, монографий, учебной литературы, но и получение представителями юридической науки грантов на исследование процессов цифровизации и сопряженной с ней международной интеграции непосредственно через призму отраслевого подхода.

В ряде работ по налоговому праву уделено значительное внимание, как отмечает Е.Г. Беликов, вопросам правового регулирования определения объектов налогообложения в отношении налогов, возникающих в связи с осуществлением деятельности на рынках цифровых услуг (например, в области электронной торговли, при использовании технологии распределенных реестров) (Belikov, 2019:23-26). Подобные проблемы требуют дальнейшего исследования, что обусловлено невозможностью применения традиционного подхода к определению понятия объекта налогообложения в новой экономической реальности. Реализация концепции цифровизации обуславливает необходимость уточнения понятия объекта налогообложения и установления соответствующих налоговых последствий в отношении новых бизнес-моделей, например, различных видов электронной коммерции в виде продажи товаров и торговли доступом к нематериальным активам, объектам интеллектуальной собственности (Pokrovskaya, 2016:171). По мнению коллег, объект налогообложения при совершении таких операций специфичен. Например, им являются доходы от результатов осуществления новых цифровых процессов, признание которых в качестве объекта налогообложения требует особых налоговых конструкций, позволяющих объективно оценить, а также справедливо и эффективно изъять часть дохода, не замедлив при этом темпы экономического развития (Koroleva, 2019:92).

В исследовательском плане нас будет интересовать проблема трансформации теоретического определения понятия объекта налогообложения в новых условиях и дискуссии относительно квалификации налоговых последствий реализации цифровых товаров при осуществлении электронной торговли. Доктринальное переосмысление понятия объекта налогообложения при этом имеет вполне прагматические цели: по справедливому замечанию Н.Т. Мамбеталиева, «динамично развивающаяся отрасль электронной торговли расширяет перечень объектов, на которые можно обратить взыскание налогов...» (Bukach, 2017:10 16). Таким образом, адекватное современным реалиям определение понятия объекта налогообложения позволит объективно оценить налоговые последствия предпринимательской деятельности для бизнеса в условиях цифровизации, а также справедливо и эффективно изъять часть доходов в казну государства, не замедлив при этом экономического роста при справедливом обеспечении и защите как частных, так и публичных интересов.

\section{Определение понятия объекта налогообложения в современной науке}

Следует отметить, что вопросы определения понятия объекта налогообложения занимают значимое место в научных трудах отечественных уче- 
ных-юристов, специализирующихся на налоговом праве: Григоров К.Н., Журавлева О.О., Ивлиева М.Ф., Кучеров И.И., Пепеляев С.Г., Смирнов Д.А., Чуркин В.А. и другие. Проблемы определения объекта налогообложения в условиях цифровизации экономики, а также необходимости отнесения к объектам налогообложения тех или иных видов доходов исследуются, например, в отношении налога на профессиональный доход в работах Копиной А.А., Мироновой С.М., Стеценко Е.Я. и других.

Осуществление обзора некоторых зарубежных научных работ по налоговому праву и налогообложению показал наличие научных публикаций в области общетеоретического понятия объекта налогообложения и его соотношения со смежными понятиями (Kucheryavenko, 2003:11-13).

Вместе с тем можно отметить, что в вопросах определения понятия объекта налогообложения и необходимости установления критериев отнесения тех или иных явлений к объектам налогообложения отсутствует единообразие подходов, что обуславливает актуальность рассмотрения объекта налогообложения с учетом современных тенденций развития науки и практики налогового права.

Традиционной для российского налогового права является характеристика объекта налогообложения путем перечисления относящихся к нему явлений, открытый перечень которых содержится в статье 38 НК РФ: реализация товаров (работ, услуг), имущество, прибыль, доход, расход или иное обстоятельство. Как известно, законодательная формулировка понятия объекта налогообложения применяется с момента вступления в силу части первой НК РФ. При этом попытки выработки каких-либо квалифицирующих признаков объекта налогообложения, которые бы позволяли однозначно идентифицировать те или иные предметы и явления окружающего мира в качестве объектов налогообложения, а также их классифицировать, на сегодняшний день не увенчались успехом. Однако у научных и практических работников, специализирующихся на налоговом праве, сформировалось два различных по своему содержанию подхода к определению понятия объекта налогообложения, которые условно можно обозначить экономическим и юридическим.

Представители экономических наук считают единственно правильным и дальше развивать законодательно закрепленную идею по формулированию понятия объекта налогообложения исключительно путем перечисления различных объектов. В этом случае своей задачей они видят оценку того или иного объекта на предмет возможности и/или необходимости законодательного установления в отношении него налоговой обязанности по уплате налога (Churkin, 2002:11). Юристы, в свою очередь, объект налогообложения рассматривают в качестве юридического факта, влекущего для субъекта возникновение обязанности по уплате налога. При этом объектом налогообложения признаются только те юридические факты, которые являются осознанными волевыми деяниями налогоплательщиков или их результатами, а именно - действия, связанные с реализацией товаров, работ, услуг или с получением дохода. Как известно, в зависи- 
мости от идентификации того или иного объекта в качестве товара, работы или услуги, налоговое законодательство устанавливает различные юридические и соответствующие им финансовые последствия в отношении сделки (ст. 3839 НК РФ), например, при исчислении и уплате НДС.

По нашему мнению, изначальный отказ от выработки критериев определения объекта налогообложения, реализуемый в экономической науке, предполагает высокую степень субъективного усмотрения государства при отнесении того или иного объекта к числу тех, в отношении которых устанавливаются налоговые обязанности. Все это приводит к мысли, что в принципе налоги могут взиматься практически со всего. Во всяком случае подобные суждения обнаруживаются в работах и других авторов (Karagusova, 1994:17). Как представляется, поэтому экономический и юридический подходы нельзя противопоставлять, поскольку они являются взаимодополняющими и конкретизируют друг друга. Надо помнить, что экономическая наука и юридическая теория имеют своим объектом сходные явления: первая изучает, как эффективнее произвести, распределить и потребить блага, вторая — как сделать это справедливо и легитимно (Napso, Napso, 2019:161). Это позволяет обеспечить равновесие в выражении публичных и частных интересов за счет признания властной принудительности права, проведенную на основе анализа реальных условий. Таким образом, в качестве объекта налогообложения в настоящее время признаются перечисленные в НК РФ явления, которые имеют установленные в законе характеристики (стоимостные, количественные, физические), и являются юридическими фактами-действиями.

По мнению автора, в сложившейся ситуации возможно использовать принципы экономического анализа для выработки моделей правового регулирования и конкретных норм. А. Раскольников, изучая взаимное влияние экономики на налоговое право, высказывал сходные мысли в общем виде вне зависимости от связи с цифровизацией (Shaviro, 2014:455).

\section{Проблемы определения понятия объекта налогообложения в цифровую эпоху}

В условиях реализации Национальной программы «Цифровая экономика» в современной России тремя основными проблемами, возникающими при определении понятия объекта налогообложения, являются следующие: объективная невозможность оценки реализационных операций в качестве потенциальных объектов налогообложения с помощью классической триады «товар, работа, услуга»; признание в качестве объекта налогообложения не единичного юридического факта, а юридического состава; актуализация вопроса установления объекта налогообложения через так называемую «налогообразующую связь» предмета и субъекта налога.

Первая проблема, состоящая в отсутствии универсальности подхода к идентификации явлений в качестве объектов налогообложения через триаду 
«товар, работа, услуга», можно продемонстрировать в отношении попытки ее применения к цифровым товарам, реализация которых происходит при осуществлении интернет-торговли. Определение понятия таких товаров, а также цифрового рынка, на котором осуществляется их обращение, в настоящее время отсутствует как на законодательном уровне, так и в судебной и иной правоприменительной практике, что отмечают специалисты (Kadar, 2015:342). В науке пока возникает дискурс только по вопросу отнесения к ним различного вида криптовалют (Savelyev, 2017:136-153). При этом реализуется значительное количество самых разнообразных товаров, которые гипотетически можно отнести к цифровым. Это означает, что сделки с такими товарами требуют адекватной правовой оценки, в том числе с точки зрения их налогово-правовых последствий.

В реальности цифровой товар может быть, например, загружен с сайта производителя, без необходимости передачи его материального носителя. Это означает, что его можно реализовать отправкой по электронной почте или выложив в Интернет, организовав соответствующий доступ. Зачастую цифровые товары представляют собой текстовые, звуковые и видеофайлы. При этом зачастую сложно определить, каким из видов товаров является цифровой товар: выступает он в качестве имущества, работы или услуги. Например, в случае реализации цифрового товара в виде временной ссылки на обучающий текстовый файл или видео- (аудио-) запись на сайте природа такого юридического факта спорна именно с точки зрения классической триады «товар, работа, услуга». C точки зрения налогового законодательства возникает вопрос: покупатель приобрел услугу по обучению, лицензию на использование сайта, услугу связи или товар в виде самой обучающей информации? В случае признания факта передачи товара в таком случае можно ли говорить о переходе права собственности на него? Ввиду ограниченного по времени срока его использования очевидно, что нельзя. С этих позиций получается, что в случае передачи информации по ссылке в постоянное использование потребителю (а при реализации цифровых товаров зачастую возможны оба варианта (как постоянный доступ, так и временный) в зависимости от стоимости) спорной является возможность ее признания товаром или услугой, не имеющей соответствующего результата (например, в случае покупки видеоурока).

Интересным примером является регулирование вопросов налогообложения при реализации цифровых товаров на территории Европейского Союза. Из содержания и смысла Директивы Европейского Союза можно сделать вывод, что цифровые и электронные продукты должны признаваться в качестве «услуг, предоставляемых в электронном виде». Там же приводится список таких услуг, к которым относятся: серверное обеспечение, размещение на сервере веб-узлов клиентов, дистанционное обслуживание программ и оборудования; поставка программного обеспечения и его обновление; поставка изображений, текстов и информации и предоставление доступа к базам данных; поставка музыки, фильмов и игр, включая азартные игры, а также политических, культурных, художествен- 
ных, спортивных, научных и развлекательных передач и трансляций; поставка дистанционного обучения. Таким образом, для всех стран Европейского Союза реализация цифровых продуктов рассматривается как новый вид услуг. Поскольку Российская Федерация не участвует в документах Европейского Союза, на ее территории необходимо собственное правовое регулирование вопросов идентификации цифровых продуктов в качестве работ или услуг как на уровне национального права, так и в актах международных сообществ, членом которых она является. Д.А. Митин полагает, что выходом в сложившейся ситуации может стать закрепление в российском налоговом законодательстве или в специальном законодательном акте, связанном с правовым регулированием цифровых прав, определений следующих категорий: «цифровой товар», «цифровая поставка», а также определение перечень цифровых товаров. По его мнению, это облегчит определение объекта налогообложения в случаях реализации цифровых товаров (Mitin, 2018:36-39). Надо полагать, что помимо собственно определения правовой природы цифровых товаров необходимо также дополнить определение понятия объекта налогообложения в п. 1 ст. 38 НК РФ в части перечисления видов услуг электронно-поставляемыми услугами, при этом определив их виды, например, по аналогии с перечнем, содержащимся в Директиве Европейского Союза 2006/112/ЕС. Также логичным считаем дополнить ст. 146 НК РФ специальными правилами, связанными с исчислением и уплатой НДС в отношении цифровых товаров, понимаемых в значении электронно-поставляемых услуг. Это позволило бы правоприменителю однозначно рассматривать все цифровые поставки в качестве нового вида услуг, применяя к ним соответствующие правила и налоговую ставку.

С точки зрения определения правовой природы новых цифровых явлений для осуществления возможности отнесения их к объектам налогообложения интересно оценить феномен криптовалют («виртуальных валют») с использованием триады «товар, работа, услуга». Как известно, на сегодняшний день в Российской Федерации большинство операций с криптовалютами осуществляется вне пределов правового регулирования, а сами криптовалюты не гарантируются и не обеспечиваются Банком России. Совершенно справедливо в аналитических материалах отмечается, что, основываясь на требованиях современного законодательства, криптовалюты (в частности, биткоин) не отвечают требованиям, обычно предъявляемым к деньгам, не могут выполнять всех их функций (Yermak, 2013).

Варианты квалификации биткоина и других разновидностей криптовалют, представленные в российской и зарубежной научной литературе, разнообразны. В частности, их оценивают как актив, который можно рассматривать как составляющую инвестиционного портфеля; иностранная валюта; квазивалюта (quasi-currency), ваучеры (vouchers) (Lambooij, 2014:140) и т.д. Наиболее часто криптовалюта рассматривается как один из видов имущества, в качестве товара или так называемого «экономического актива» (Matsuura, 2016:45-47). 
Можно заметить, что правовое регулирование налоговым законодательством последствий сделок, совершаемых с криптовалютами, в зарубежных странах является приоритетным перед вопросом определения их правовой природы. Например, в США на сегодняшний день создано наиболее комплексное налогово-правовое регулирование применения блокчейн-технологий и виртуальных денег, причем как на федеральном уровне, так и в нормативных правовых актах штатов (субъектов федерации). Криптовалюты в этом государстве квалифицируются как имущество, инвестиционный инструмент или иностранная валюта (Wiseman, 2016:417-440). Таким образом, чаще всего криптовалюту пытаются идентифицировать с помощью известных правовых терминов и конструкций на основании так называемого «бартерного» подхода, реализуемого за счет переноса гражданско-правовой терминологии на налоговые отношения.

Немало и критиков «бартерного» подхода, подчеркивающих, что правила, созданные для сделок с традиционным имуществом, не учитывают принципиальную особенность виртуальных валют - использование в качестве средства обмена, и механическое применение старых принципов ведет к неудовлетворительному результату. Такой подход оценивается как несовершенный и с позиции продвижения неосуществимых или труднореализуемых норм (Hampton, 2016:331, 334).

Сходный подход к первичности установления правил налогообложения криптовалют перед вопросом определения их правовой природы реализуется и в Российской Федерации. Так, Минфин России считает, что операции с криптовалютами должны облагаться НДФЛ, напоминая при этом, что в соответствии с положениями ст. 228 НК РФ физические лица должны самостоятельно исчислять и уплачивать налог, получая вознаграждение от физических лиц на основе договоров гражданско-правового характера. Иными словами, если одно физлицо продает биткоины другому физлицу, то должно самостоятельно определить налоговую базу, отчитаться о полученных доходах, рассчитать и уплатить налог. При этом Минфин России ссылается на положения ст. 41 НК РФ об определении доходов.

При этом несколько лет назад Банк России предостерегал граждан и юридических лиц от использования «виртуальных валют» для обмена на товары (работы, услуги) или на денежные средства в рублях и иностранной валюте.

Второй проблемой, связанной с определением понятия объекта налогообложения в цифровую эпоху, является необходимость в качестве такого объекта рассматривать не один юридический факт, а их совокупность в виде юридического состава. Примером является оплата реализуемых товаров с помощью электронных денег, которые рассматриваются в качестве эквивалента реальных (фиатных, как их называл Джон Мейнард Кейс (Cesarano, 2008:124), номинальная стоимость которых устанавливается и гарантируется государством вне зависимости от стоимости материала, из которого они изготовлены, или находящиеся в хранилище банка) денежных средств, но обращаются только внутри конкретной 
электронной платежной системы (Яндекс.Деньги, QIWI, E-port и другие) (Grishina, 2019:21-27). Механизм расчетов с использованием электронных денег основывается на том, что они представляют собой право требования владельца электронных денег к оператору об их погашении (обмене на наличные или безналичные денежные средства). Электронные денежные средства учитываются на специальном виртуальном счете («электронном кошельке»), при этом на банковском счете оператора электронных денежных средств отражаются денежные средства, за счет которых будут погашаться все электронные денежные средства, учитываемые оператором электронных денежных средств. Еще одна деталь, что до осуществления перевода электронных денежных средств предполагается их предоплата наличными деньгами или безналичными денежными средствами, после этого возникает возможность совершить платеж - оператор электронных денежных средств переводит их получателю. Перевод может осуществляться как на основании распоряжения плательщика, так и на основании требования получателя денежных средств. Электронные денежные средства списываются с виртуального счета («электронного кошелька») плательщика и зачисляются на виртуальный счет получателя (Tsindeliani (ed.), 2019:320).

Следует заметить, что, в соответствии с официальной позицией Минфина России, доход, полученный при оплате покупателями приобретенных товаров электронными денежными средствами, является объектом налогообложения, а факт оплаты подтверждается выпиской по соответствующему счету у оператора платежной системы или сообщением оператора платежной системы. Таким образом, объект налогообложения в этом случае может возникнуть в результате не одного, а двух юридических фактов, один из которых по отношению ко второму является обеспечительным условием.

При этом какие-либо изменения в налоговом законодательстве Российской Федерации, связанные с необходимостью фиксирования последствий не от одного, а от двух юридических фактов, для возможности установления обязанности по уплате налога в отношении того или иного предмета налога, отсутствуют. Полагаем, что логичным было бы в связи с этим скорректировать п. 1 ст. 38 НК РФ в вопросе определения понятия объекта налогообложения, указав, что им может быть юридический состав. В такой состав включается не только обстоятельство, но и совокупность обстоятельств, одно из которых имеет стоимостную характеристику, а другое - организационно-обеспечительную природу.

Третьим вызовом цифровизации налоговому праву в части формулирования понятия объекта налогообложения является актуализация вопроса установления при определении налога необходимости налогообразующей связи между предметом налога как явлением материального мира и потенциальным налогоплательщиком. О наличии такой связи заявлял Е.В. Порохов, при этом определяя ее как устойчивую правовую связь субъекта налога с предметом налогообложения (Porokhov, 2001:99). И.И. Кучеров подчеркивал важность этой связи для реального установления факта наличия или отсутствия объекта нало- 
гообложения в деятельности потенциального налогоплательщика: «Эта связь является определяющей, поскольку, по нашему мнению, как раз и формирует объект налога - наиважнейший элемент его юридической конструкции» (Kucherov, 2009:2-5). Фактически это означает, что для отнесения того или иного юридического факта к объектам налогообложения необходимо установить юридическую связь предмета материального мира (предмета налога) с физическим лицом, имея при этом механизм однозначной идентификации последнего. В условиях цифровизации возникают сложности определения личностей участников сделки, а также их местоположения и статуса, что является значимым с точки зрения налогообложения при осуществлении электронных сделок.

В качестве одного из проявлений проблемы сложности идентификации установления «налогообразующей связи» предмета и субъекта налогообложения, например, является вопрос правомерности удостоверения сделок при использовании аналогов собственноручной подписи.

В качестве временного решения проблемы ОЭСР было предложено использовать цифровые свидетельства и цифровые подписи для идентификации сторон сделок, последствия которых облагаются налогом, что обеспечит возможность идентификации конкретного субъекта в качестве налогоплательщика, имеющего отношение к определенному благу, в отношении которого государством может быть установлена обязанность по исчислению и уплате налога.

Как известно, в национальном законодательстве Российской Федерации использование при совершении сделки аналогов собственноручной подписи регулируется гражданским законодательством (п. 2 ст. 160 ГК РФ). Исследователи отмечают, что «проецирование» этих положений на налоговые и иные отношения, не являющиеся гражданско-правовыми, возможно только при наличии соответствующего указания на эту возможность в законе. Представляется, что сложность применения возможности использования цифровых свидетельств и цифровых подписей сторонами сделки, последствия которой являются налогооблагаемыми, связана именно с отсутствие таких специальных положений в налоговом законодательстве.

\section{Заключение}

Таким образом, результатом взятого государством курса на развитие цифровой экономики является существенная трансформация как теории налогового права, так и его правового регулирования. Представляется, что для реализации возможности внедрения новых технологий в налоговые отношения необходимо осуществлять исследования, нацеленные на освоение отдельных, относительно узких, хотя бесспорно важных и требующих решения проблем, связанных с использованием цифровых технологий в правовой сфере (Khabrieva, 2018:6). По этой причине вопросы определения понятия объекта налогообложения требуют дальнейшего изучения и разработки. 
Проведенный в рамках настоящей научной статьи обзор академической литературы по вопросу определения понятия одного из важнейших терминов налогового права - объекта налогообложения - позволяет сделать вывод о наличии двух подходов к такому определению, каждый из которых с учетом современных цифровых вызовов российской экономике представляется неидеальным. Кроме того, однозначного обновления требует налогово-правовая терминология, в частности, за счет нормативного определения цифрового товара.

Представляется, что основной недостаток актуального определения понятия объекта налогообложения состоит в моральном устаревании подходов к его формулированию. По нашему мнению, прежде всего необходима доктринальная концепция трансформации налоговых отношений в цифровую эпоху, на основании которой станет реальной возможность дальнейшего совершенствования налогового законодательства. При этом в такой концепции должно акцентироваться внимание на выработке новой терминологии, а также адекватной цифровым реалиям методологии, предполагающей использование для целей налогового права комплексного подхода. Такой подход должен сочетать в себе применение юридических, экономических, социологических знаний в сочетании с информационными технологиями.

Практическая ценность такого подхода состоит в создании универсальной триединой формулы - «правовое регулирование, государственное управление, технологии», выступающей в качестве основной концептуальной идеи дальнейшей цифровизации как российской экономики, так и деятельности государственных органов. Действительно, успешное внедрение тех или иных новых технологий в процессы взаимодействия частных и публичных субъектов успешно реализуется исключительно в случае предварительного обоснования того, какое управленческое решение должно быть реализовано за счет таких технологий, а также при условии обеспечения соответствующих модификаций нормативным правовым и индивидуальным регулированием.

Полагаем, что концептуальную ценность идея обеспечения единства технологий, права и государственного управления имеет не только в отношении отдельных сфер, например, налогообложения. На наш взгляд, она характеризуется универсальным характером, в связи с чем должна использоваться в качестве методологической основы цифровой трансформации деятельности государственных и муниципальных органов.

\section{Об авторе:}

Лютова Ольга Игоревна - кандидат юридических наук, научный сотрудник Института государственного и муниципального управления Национального исследовательского университета «Высшая школа экономики»

ORCID: 0000-0002-6603-8859

e-mail: olyutova@hse.ru 